DOI: $10.2478 /$ lpts-2020-0002

\title{
MODELLING OF SIPM PERFORMANCE FOR DETECTION OF CHERENKOV RADIATION FROM EXTENSIVE AIR SHOWERS IN UV AND VISIBLE RANGES FOR APPLICATION AT THE TAIGA-IACT TELESCOPE
}

\author{
A.A. Bogdanov*, E.E. Kholupenko, \\ Yu.V. Tuboltsev, Yu.V. Chichagov
}

Ioffe Institute, 26 Politekhnicheskaya Str., 194021, St. Petersburg, RUSSIA

*e-mail: Alexander.A.Bogdanov@mail.ioffe.ru

A novel cluster of sensitive detectors based on silicon photomultipliers (SiPM) is being developed for the Cherenkov gamma-ray telescope TAIGAIACT (Tunka valley, Republic of Buryatia, Russia). The cluster will be able to detect Cherenkov radiation from extensive air showers in two wide bands: 250-300 nm (UV) and 250-700 nm (visible and UV). Each pixel consists of a Winston cone, $4 \mathrm{SiPMs}$ with the total sensitive area of $144 \mathrm{~mm}^{2}$, and readout electronics based on fast analogue memory. During operation in the UV band, a UV-bandpass filter is used to suppress cluster sensitivity in the visible range. In order to evaluate the detection efficiency of the selected SiPMs, a specific software simulator of SiPM output signal has been developed. This simulator takes into account such inherent parameters of SiPMs as total number of microcells, their recharge time, the dark count rate, the effective detection area, the quantum efficiency, the crosstalk between microcells, as well as conditions of SiPM operation, namely, the background noise and the Ohmic load in the readout (front-end) electronics. With this simulator it is possible to determine the expected trigger threshold under given conditions and parameters of selected detectors. Based on preliminary simulations, OnSemi MicroFJ-60035 SiPM chips have been chosen for the novel cluster of TAIGA-IACT. These SiPMs have sensible efficiency in the ultraviolet range (5-20\% in the 250-300 $\mathrm{nm}$ band) and are distinguished by the presence of a fast output, which allows one to capture a low amplitude signal above a relatively high background noise.

Keywords: Extensive air shower, IACT, photomultipliers, SiPM

\section{INTRODUCTION}

Gamma-ray astronomy is an important field of observational astrophysics. It allows one to investigate the most energetic events in the Galaxy and beyond, such as explosions at late stages of stellar evolution [1], stellar mergers, propagation of interstellar shock waves, and intense high-velocity outflows (jets) formed in the 
vicinity of super massive black holes in active galactic nuclei [2]. Modern methods for observing high energy cosmic gamma-quanta cover the range up to $\sim 100 \mathrm{TeV}$ [3], [4] and even beyond [5].

Cherenkov gamma-ray telescopes and their arrays - Cherenkov gammaray observatories - are the most sensitive instruments suited for observations of cosmic gamma-rays in the $10 \mathrm{GeV}-100 \mathrm{TeV}$ range because of their effective area (about $10^{4}-10^{6} \mathrm{~m}^{2}$ ). Rather than registering the primary gamma-quantum, they detect Cherenkov radiation generated by high-energy electrons and positrons of extensive air showers (EASs) induced by the primary gamma-quantum during its interaction with the Earth's atmosphere. The Cherenkov radiation from an EAS is emitted within a narrow cone in the motion direction of the primary particle and illuminates an area with diameter of 200-500 $\mathrm{m}$ (depending on primary particle energy [4], [6]) on the Earth's surface.

At major modern imaging atmospheric Cherenkov telescopes (IACTs) and observatories (MAGIC, VERITAS, H.E.S.S.), measurements of Cherenkov light flashes are performed using cameras based on high-voltage vacuum photomultiplier tubes (PMTs). This leads to significant restrictions of available exposure because Moon illumination and atmosphere illumination during twilight may cause full blinding or even fatal damage of these PMTs. In this regard, it is likely that semiconductor avalanche photodetectors - silicon photomultipliers (SiPM) - will be used in the detector blocks of the foreseen telescopes of the new (fourth) generation (for example, CTA and ALEGRO [7]). At present, employment of SiPM-based camera at FACT telescope already allows one to perform observations even during moonlit nights [8], and it significantly enlarges exposures of cosmic gamma-ray sources. An additional almost equally efficient method to increase the duty cycle is the use of UV-pass filters blocking optical emission (e.g., [9], [10]). This approach leads to strong suppression of the noise in the telescope camera induced by the night sky background and Moon illumination and conservation of a significant part of the EAS Cherenkov signal, as its spectrum peaks at 300-330 nm.

Currently, a novel cluster of 28 sensitive SiPM detectors with replaceable UV filters is being developed for the Cherenkov gamma-ray telescope TAIGA-IACT (Tunka valley, Republic of Buryatia, Russia) in order to probe both mentioned techniques of duty cycle extension and to improve the gamma-hadron separation. Such techniques are likely to be employed at larger-scale Cherenkov observatories (e.g., ALEGRO [7]). Within the next 2-3 years, it is planned to replace one of 20 PMT-based detecting clusters of one TAIGA-IACT unit [4] by a new cluster based on OnSemi MicroFJ-60035 SiPMs (further on -“MicroFJ"). In the frame of this project, numerical modelling of the TAIGA-IACT telescope unit and, in particular, modelling of the new detecting cluster are required. Such modelling includes development of a MicroFJ pixel simulator, which is the subject of the present paper.

\section{PARAMETERS OF CHERENKOV FLASH SIGNALS TO BE REGISTERED WITH TAIGA-IACT}

A flash of 260-700 nm Cherenkov light produced by an EAS and later focused by a mirror of an IACT is short (about 10-15 ns) and weak (the integral fluxes 
registered by modern Cherenkov telescopes are $\sim 3-3 \cdot 10^{4}$ photon $/ \mathrm{m}^{2}$ ). The leading edge of such a signal is about 2-3 ns long (depending on the primary particle type). At distances $\mathrm{r}<120 \mathrm{~m}$ from the EAS axis, over $90 \%$ of Cherenkov photons will come within a $10 \mathrm{~ns}$ interval. The TAIGA-IACT telescope has the mirror area of about $10 \mathrm{~m}^{2}$, a $10^{\circ}$ field of view (FoV) [4], the camera pixel area of about $9.5 \mathrm{~cm}^{2}$. With an account of the telescope optical transmission coefficients and the photon detection efficiency (PDE) of present detectors, this leads to $\sim 1 \mathrm{TeV}$ energy threshold of this instrument. Preliminary modelling of TAIGA-IACT shows that Cherenkov radiation from EAS induced by a cosmic gamma-quantum with energy $1 \mathrm{TeV}$ would yield a signal of about 13 photoelectrons (p.e.) per detector pixel for a $10 \mathrm{~ns}$ frame (hereafter 1 p.e. means the signal from 1 triggered SiPM detector microcell, i.e., 1 electron avalanche, since microcells operate in the Geiger mode). Note that the signal in individual brightest pixels can be 3-7 times higher than the indicated average value and may reach $\sim 10^{2}$ p.e./frame.

Since the signal from an EAS is generated by the Cherenkov radiation, its spectrum (illustrated in Fig. 1) is described by the Frank-Tamm law averaged over ensembles of ultra-relativistic electrons and positrons of EAS moving with energies larger than the critical value ( $21 \mathrm{MeV}$ near the Earth surface), with a cutoff below $\sim 300 \mathrm{~nm}$, which is due to absorption of photons by atmospheric ozone.

The level of night sky background depends on locality (defined by the latitude and longitude), climate, and day time. The typical background level for the Tunka valley on a moonless night is about $3 \cdot 10^{12}$ photon $\cdot \mathrm{m}^{-2} \cdot \mathrm{s}^{-1} \cdot \mathrm{sr}^{-1}$ in the $300-600 \mathrm{~nm}$ band. For the TAIGA-IACT telescope, the modelled noise from background photons would amount to $(2.5 \pm 0.8)$ p.e. in a $10 \mathrm{~ns}$ frame. A typical spectrum of night sky background is shown in Fig. 1 (based on data from [11]).

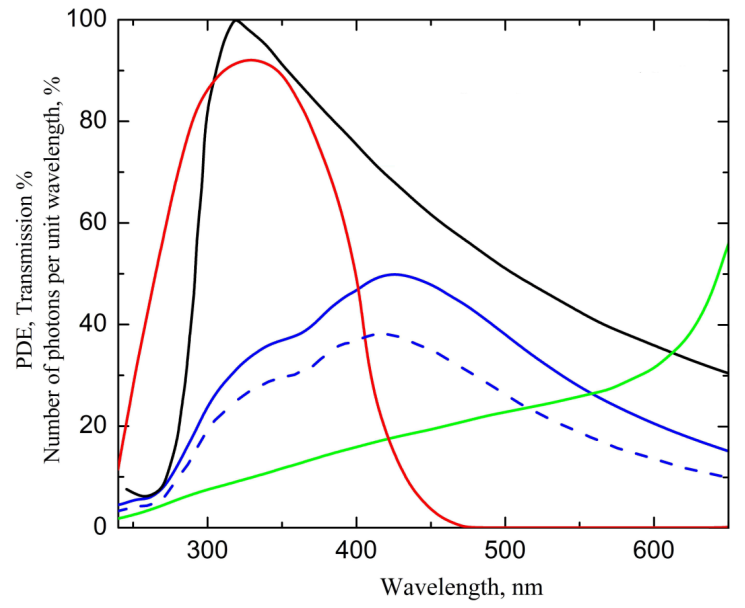

Fig. 1. Model spectra of source signal and sky background along with typical wide UV filter transmission and detector efficiency: black - a typical Cherenkov flash spectrum, green - night sky background spectrum; blue - the PDE of OnSemi MicroFJ60035 at $6 \mathrm{~V}$ (solid) and $2.5 \mathrm{~V}$ (dashed) overvoltage; red - a commercial Subei/ZWB3 wide UV filter [9] transmission curve.

As the foreseen operation range of TAIGA-IACT telescope with an upgraded camera is $1-100 \mathrm{TeV}$, with an account of the modelled background and EAS signal 
strength, one may expect that the signal from one camera pixel consisting of 4 SiPM detectors would not exceed $10^{4}$ p.e. for a $10 \mathrm{~ns}$ frame. It is quite acceptable because the number of microcells in such a pixel would be about $9 \cdot 10^{4}$. The signal range of $1-10^{4}$ p.e. is a requirement for the front-end readout system currently developed at the Ioffe Institute.

\section{MODELLING OF DETECTOR PERFORMANCE}

The developed model of OnSemi MicroFJ-60035 SiPM [12] detector pixel accounts for photon registration within detector microcells, dark counts, crosstalk, background noise from the night sky, and formation of the output electric signal. For simplicity, the internal detector noise and the noise from readout chains are not taken into account. No broadening of the output signal due to these chains has been considered.

Detector modelling yields oscillograms of the output signal, which are based on the evolution of the number of triggered microcells (or photoelectrons, further p.e.), as the amplitude of the whole SiPM signal is proportional to the number of avalanched microcells. As the capacity of the SiPM detector $C_{\mathrm{DET}}$ and the readout resistance $R$ are significant, the signal amplitude decays with non-zero time constant (see Fig. 2).

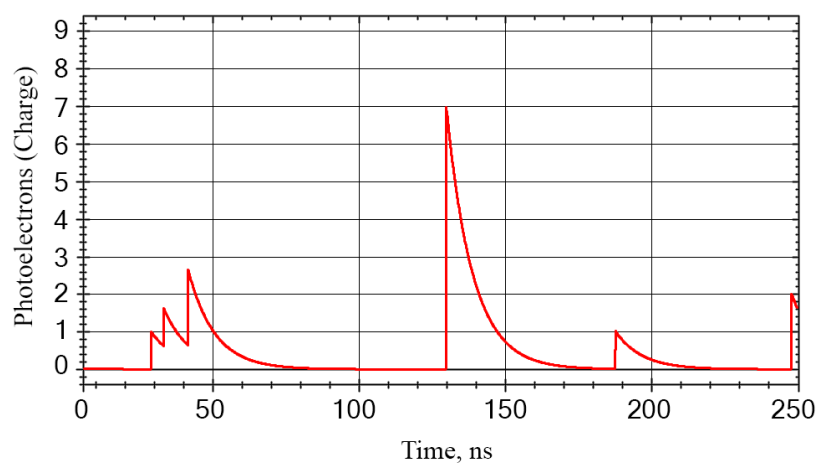

Fig. 2. A model detector oscillogram. The signal at 130 ns comes from source photons (6 p.e.) and a crosstalk event (1 p.e.).

For illustrative purposes, a toy-model $14 \times 14$ microcell detector is shown in Fig. 3, while the number of microcells in a real detector can reach several by ten thousand. We have modelled a SiPM-based detector consisting of $2 \times 2$ MicroFJ chips and amounting to 89168 microcells.

Each of the green microcells in Fig. 3 corresponds to a source photon, which adds 1 p.e. to the summed amplitude of the model output signal. Each of the triggered microcells may also initiate an avalanche in one of the neighbouring cells (at an $8 \%$ crosstalk probability for $+2.5 \mathrm{~V}$ overvoltage [12]), which also adds 1 p.e. to the output.

Crosstalk is a significant mechanism affecting the output signal of SiPM detector. A simplified explanation of crosstalk is that an infrared (IR) photon may 
be emitted in a microcell within the avalanche process triggered either by a source/ background photon or by a dark current event. If such an IR photon is energetic enough, it can trigger an avalanche in one of the neighbouring microcells. Hence, the output amplitude of the detector becomes uncertain, and this uncertainty rises with the crosstalk probability [13].

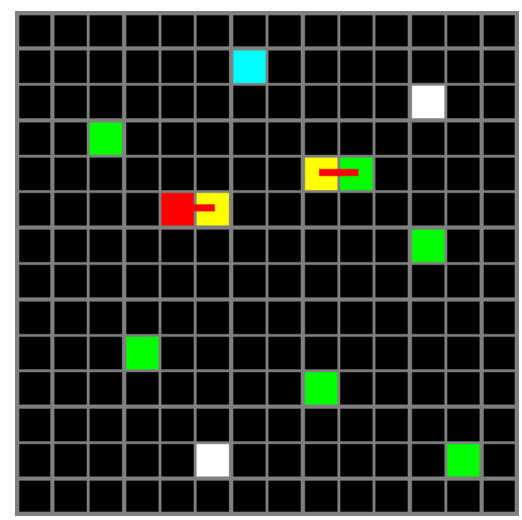

Fig. 3. A toy-model $14 \times 14$ microcell detector pixel with various types of events shown: source (green), crosstalk (yellow), hit twice within the relaxation time (red), sky background (white), dark counts (cyan). The red bars indicate the crosstalk direction.

The crosstalk simulation algorithm is as follows. Once a microcell is triggered, one of the neighbouring microcells will also be triggered with a certain probability (e.g., $8 \%$ ) and according to the "4 nearest neighbours" model [13]. Moreover, a chain of crosstalk triggered microcells may be formed because they can also cause IR-photons. In practice, such chains are rarely larger than 2 or 3 microcells. We do not consider here the delayed crosstalk [14] and the afterpulsing activity of the MicroFJ detector.

Crosstalk-induced microcells are shown in yellow (Fig. 3), and the crosstalk direction is shown with a red bar. After a microcell is triggered either by a source or background photon, or by crosstalk, or dark count event, its input to the summed detector signal evolves according to discharge of the corresponding $\mathrm{RC}$ contour, i.e., the signal decays $\sim \exp \left(t / R C_{\mathrm{DET}}\right)$, where $t$ is time, $R$ is the load resistance.

\section{DETECTOR BACKGROUND AND DARK COUNT RATE}

The dark count rate of silicon photomultipliers is much higher than that of traditional vacuum photomultipliers. Together with the background photons they decrease the signal-to-noise ratio. At $+2.5 \mathrm{~V}$ overvoltage, the dark count rate of MicroFJ SiPM detectors is about $50 \mathrm{kHz} / \mathrm{mm}^{2}$; hence, for a $2 \times 2$ MicroFJ SiPM pixel proposed for the camera of TAIGA-IACT it would yield the rate $\sim 7 \mathrm{MHz} /$ pixel. Such a rate is not significant for observations in the visual band, where the dark sky background is about $\sim 250 \mathrm{MHz} /$ pixel ( 2.5 p.e. for a $10 \mathrm{~ns}$ frame), but in the 250-300 nm band it becomes an important issue, as the dark sky background in the ultraviolet range is substantially lower $(<1 \mathrm{MHz} /$ pixel $)$. 
It should be noted that reading out from the fast output of MicroFJ SiPM (RC constant $\sim 3 \mathrm{~ns}$ ) would allow us to avoid charge accumulation even for the relatively high sky background expected in the visual band; hence, individual pulses are not likely to overlay and saturate the output.

\section{MICROCELL RELAXATION AND DETECTOR SATURATION}

A triggered microcell cannot produce an avalanche signal until it is recharged. The characteristic recharge time constant for MicroFJ is about $50 \mathrm{~ns}$ [12]. As the number of microcells in a SiPM detector is large and the expected background is relatively low, the simulation software marks the triggered microcells (red in Fig. 3) if a photon hits it during the full recharge time (about $150 \mathrm{~ns}$ ), but does not enhance the modelled output signal. In practice, there is a small chance that a microcell that has not fully recharged still produces an avalanche.

For the TAIGA-IACT camera, the expected background photon rate in an optical pixel containing 4 MicroFJ SiPM detectors is about $250 \mathrm{MHz}$, and the dark count rate is about $7 \mathrm{MHz}$. As the total number of microcells in such a pixel equals 89168 , the probability of a photon hitting a microcell during its recharge is about $0.05 \%$. The expected number of optical range photons from an EAS is about 150; hence, the probability of such a photon to hit a recharging microcell in a $10 \mathrm{~ns}$ frame is about $18 \%$, which would lead to $<1 \%$ uncertainty of the EAS signal.

We have modelled detector saturation at maximal foreseen photon loads (about $10^{4}$ photons in a $10 \mathrm{~ns}$ frame). Such a photon signal would trigger on average $(11.5 \pm 0.1) \%$ of the total 89168 microcells. The output signal appeared only about $2 \%$ higher than $10^{4}$ p.e. because about $6 \%$ of the incoming photons and crosstalk events overlapped with the already triggered microcells. Hence, we concluded that the detector would keep linear and would not saturate at the modelled loads.

\section{EVALUATION BOARD FOR A MICROFJ-BASED DETECTOR}

We have fabricated and investigated a simple evaluation board for a MicroFJbased detector (Fig. 4). The input stage consists of a current follower on a BFT93 transistor and a voltage amplifier on a wideband low-noise operational amplifier AD8099. This input stage provided amplification and conversion of detector current from the fast output with transimpedance $1600 \Omega$ in a bandwidth of more than $200 \mathrm{MHz}$.
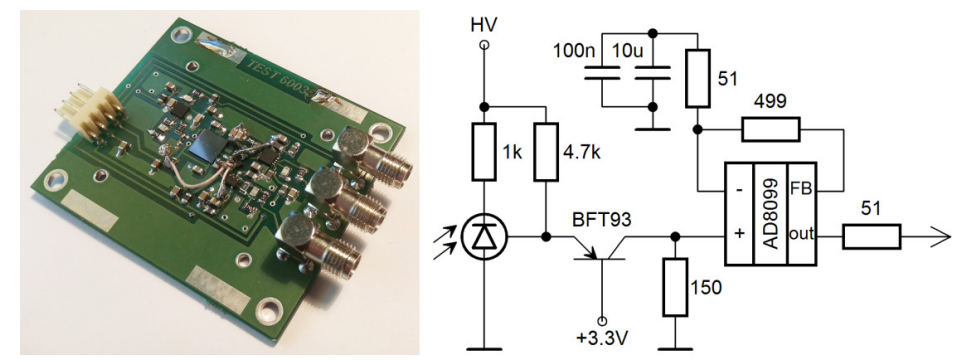

Fig. 4. An evaluation board for a MicroFJ-based detector pixel produced by the authors. 


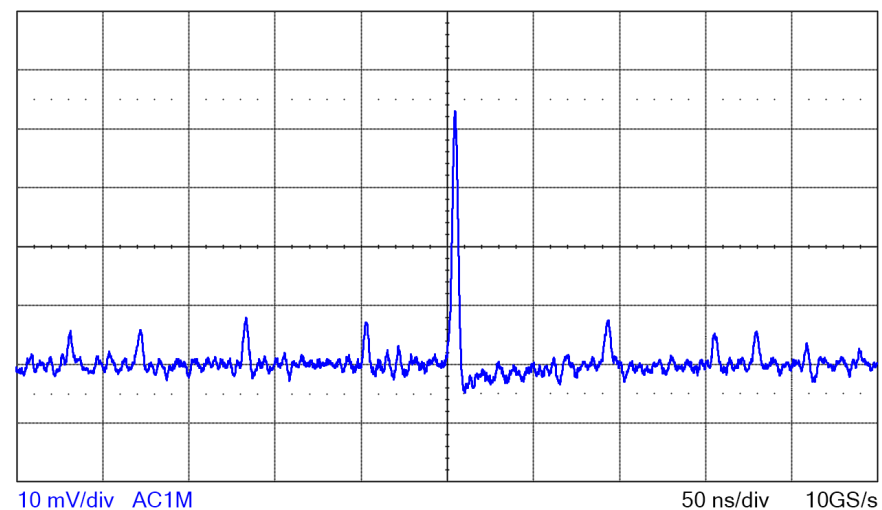

Fig. 5. Dark count signal measured from SiPM detector OnSemi MicroFJ-60035 at $+2.5 \mathrm{~V}$ overvoltage. The widths of the leading and trailing edges were about $3 \mathrm{~ns}$. The vertical box scale is $10 \mathrm{mV}$; the horizontal scale is $50 \mathrm{~ns}$.

Experiments in a dark volume have shown that the widths of the leading and trailing edges are about 3 ns. A dark current impulse on top of multiple crosstalk events observed with frequency $\sim 1 \mathrm{~Hz}$ is shown in Fig. 5. The amount of crosstalk in such peaks can be approximately estimated from this frequency and known crosstalk probability $(8 \%)$ as 7 p.e. ( 1 microcell triggered by dark current and 6 crosstalk events).

\section{CONCLUSIONS}

We have modelled parameters of output signals from a Cherenkov telescope pixel made of 4 SiPM MicroFJ detectors for realistic photon loads. The modelling accounted for microcell crosstalk, dark counts, sky background and source parameters, as well as for some parameters of readout electronics. Based on this modelling, we may conclude that such SiPM-based pixels can be employed for future upgrade of the TAIGA-IACT camera and proceed to optimisation of the camera front-end readout scheme.

\section{ACKNOWLEDGEMENTS}

The research has been supported by $R S F$ grant 19-72-20045.

\section{REFERENCES}

1. Brazier, K.T.S., Carraminana, A., Chadwick, P.M., Dipper, N.A., Lincoln, E.W., McComb, T.J.L., ... \& Turver, K.E. (1990). SN1987a - Updated Limit to $400 \mathrm{GeV}$ Gamma Ray Emission Using the Narrabri VHE Gamma Ray Telescope - May 1989. Nucl. Phys. B. Proc. Suppl., 14 (1), 188-190.

2. Ahnen, M.L., Ansoldi, S., Antonelli, A., Antoranz, P., Babić, A. Banerjee, B., ... \& Zottmann, N. (2015). Very High Energy $\gamma$-Rays from the Universe's Middle Age: Detection of the $\mathrm{z}=0.940$ Blazar PKS $1441+25$ with MAGIC. The Astrophysical Journal Letters, 815 (2), L23-L31. 
3. Aharonian, F., Akhperjanian, A., Beilicke, M., Bernlöhr, K., Börst, H.-G., Bojahr, H., ... \& Wittek, W. (2004). The Crab Nebula and Pulsar between $500 \mathrm{GeV}$ and $80 \mathrm{TeV}$ : Observations with the HEGRA Stereoscopic Air Cerenkov Telescopes. The Astrophysical Journal, 614 (2), 897-913.

4. Kuzmichev, L.A., Astapov, I.I., Bezyazeekov, P.A., Boreyko, V., Borodin, A.N., Budnev, B.M., ... \& Yashin, I.I. (2018). TAIGA Gamma Observatory: Status and Prospects. Physics of Atomic Nuclei, 81 (4), 497-507.

5. Amenomori, M., Bao, Y.W., Bi, X.J., Chen, D., Chen, T.L., Chen, W.Y., ... \& Zhou, X.X. (2019). First Detection of Photons with Energy Beyond $100 \mathrm{TeV}$ from an Astrophysical Source. eprint arXiv:1906.05521.

6. Mishev, A., Mavrodiev, S., \& Stamenov J. (2005). Gamma Rays Studies Based on Atmospheric Cherenkov Technique at High Mountain Altitude. International Journal of Modern Physics A, 20 (29), 7016-7019.

7. Bykov, A. M., Aharonian, F. A., Krassilchtchikov, A. M., Kholupenko, E.E., Aruev, P.N., Baiko, D.A., ... \& Chicagov, Yu.V. (2017). Cherenkov Gamma-Ray Telescopes: Past, Present, Future. ALEGRO Project. Technical Physics, 62 (6), 819-836.

8. Knoetig, M. L., Biland, A., Bretz, T., Buß, J., Dorner, D., Einecke, S., ... \& Zanglein, M. (2013). FACT - Long-term Stability and Observations during Strong Moon Light. In Proc. of the 33rd ICRC, Rio de Janeiro, id. 695, arXiv:1307.6116.

9. Guberman, D., Cortina, J., Garcia, R., Herrera, J., Manganaro, M., Moralejo, A., ... \& Will, M. (2015). Using UV-pass Filters for Bright Moon Observations with MAGIC. In Proc. of the 34th International Cosmic Ray Conference (ICRC2015), 34, id. 1237, arXiv:1509.02048.

10. Kholupenko, E.E., Bykov, A.M., Aharonyan, F.A., Vasiliev, G.I., Krassilchtchikov, A.M., Aruev, P.N., ... \& Nikolaev, A.V. (2018). Detection of UV Radiation from Extensive Air Showers: Prospects for Cherenkov Gamma-Ray Astronomy. Technical Physics, 63 (11), 1603-1614.

11. Leinert, Ch., Bowyer, S., Haikala, L.K., Hanner, M.S., Hauser, M.G., Levasseur-Regourd, A.-Ch., ... \& Witt, A.N. (1998). The 1997 Reference of Diffuse Night Sky Brightness. Astronomy and AstrophysicsSupplement, 127, 1-99.

12. Semiconductor Components Industries. (2018). OnSemi J-Series SiPM Sensors Datasheet. Rev. 6, MICROJ-SERIES/D. Available at https://www.onsemi.com/pub/ Collateral/MICROJ-SERIES-D.PDF

13. Gallego, L., Rosado, J., Blanco, F., \& Arqueros F. (2013). Modeling Crosstalk in Silicon Photomultipliers. JINST8 P05010. http://dx.doi.org/10.1088/1748-0221/8/05/P05010

14. Nagy, F., Mazzillo, M., Rennet, L., Valvo, G., Sanfilippo, D., Carbone, B., ... \& Molnar, J. (2014). Afterpulse and Delayed Crosstalk Analysis on a STMicroelectronics Silicon Photomultiplier. Nuclear Instruments and Methods in Physics Research Section A 759, $44-49$. 


\title{
SIPM VEIKUMA MODELĒ ŠANA ČERENKOVA STAROJUMA NOTEIKŠANAI NO PLA ŠĀM GAISA LIETUSGĀZĒM UV STARU UN REDZAMĀ DIAPAZONĀ PIELIETOŠANAI TAIGA-IACT TELESKOPĀ
}

\author{
A.A. Bogdanovs, E.E. Kholupenko, Yu.V. Tubolcevs, \\ Yu.V. Čičagovs
}

Kopsavilkums

\begin{abstract}
Čerenkova gamma staru teleskopam TAIGA-IACT (Tunkas ieleja, Burjatijas Republika, Krievija) tiek izstrādāts jauns jutīgu detektoru klasteris, kura pamatā ir silīcija fotopavairotāji (SiPM). Klasteris spēs noteikt Čerenkova starojumu no plašām gaisa lietusgāzēm divās platjoslās: 250-300 nm (UV) un 250-700 nm (redzamā un UV staru diapazonā). Katru pikseli veido Vinstona konuss, 4 silīcija fotopavairotāji ar kopējo jutīguma laukumu $144 \mathrm{~mm}^{2}$ un nolasīšanas elektroniku, kuras pamatā ir àtra analogā atmiņa. Darbības laikā UV joslā tiek izmantots UV joslas caurlaidības filtrs, lai nomāktu klastera jutīgumu redzamā diapazonā. Lai novērtētu izvēlēto SiPM noteikšanas efektivitāti, ir izstrādāts īpašs programmatūras simulators SiPM izejas signālam. Šis simulators ņem vērā tādus SiPM raksturīgos parametrus kā kopējo mikrošūnu skaitu, to uzlādes laiku, tumšo skaitī̌sanas ātrumu, efektīvo noteikšanas laukumu, kvantu efektivitāti, šķērsrunu starp mikrošūnām, kā arī SiPM darbības apstākḷus, proti, fona troksni un omu slodzi nolasī̌sanas (priekšgala) elektronikā. Ar šo simulatoru ir iespējams noteikt paredzamo sprūda slieksni, ņemot vērā noteiktus apstākḷus un izvēlēto detektoru parametrus. Par pamatu n,emot provizoriskās simulācijas, jaunajam TAIGA-IACT klasterim ir izvēlētas OnSemi MicroFJ-60035 SiPM mikroshēmas. Šiem SiPM ir saprātīga efektivitāte ultravioletā starojuma diapazonā (5-20\% diapazonā no 250 līdz $300 \mathrm{~nm}$ ), un tos atškir ar ātru izeju, kas lauj uztvert zemas amplitūdas signālu virs relatīvi augsta fona trokšṇa.
\end{abstract}

Atslēgas vārdi: IACT, fotopavairotāji, plaša gaisa lietusgāze, SiPM 